\title{
ARE THE CRITERIA OF METABOLIC SYNDROME ASSOCIATED WITH PREGNANCY COMPLICATIONS?
}

\author{
Banu DANE ${ }^{1}$, Fatma USTAOGLU ${ }^{1}$, Yasemin YILDIRIM1, ${ }^{1}$ asemin DOVENTAS ${ }^{2}$, Cem DANE$^{1}$, \\ Ahmet CETIN', Mustafa YENIGUN ${ }^{3}$ \\ ${ }^{1}$ Department of Obstetrics and Gynecology, Haseki Training and Research Hospital, Istanbul, Turkey \\ 2 Department of Biochemistry, Haseki Training and Research Hospital, Istanbul, Turkey \\ ${ }^{3}$ Department of Internal Medicine, Haseki Training and Research Hospital, Istanbul, Turkey
}

\begin{abstract}
SUMMARY
Aim: We aimed to compare the components of metabolic syndrome in cases with various pregnancy complications and normal pregnancies.

Materials and methods: Ninety two cases after 26. gestational week which were followed up in our clinic were included in the study. The rate of the presence of the factors of metabolic syndrome in 40 healthy pregnant women, 21 cases of gestational hypertention, 20 cases of gestational diabetes and 11 cases of preeclampsia were compared. Fasting serum cholesterol, triglyceride, LDL and HDL cholesterol levels were determined.The insulin resistance was calculated with HOMA-IR.

Results: Mean levels of BMI were significantly higher in the group of pregnancy complications (GHT 33.5.1, preeclampsia $30.3 \pm 7.1$, GDM 32.1 \pm 6.4 , and controls 29.2 $4.2 \mathrm{~kg} / \mathrm{m} 2 ; \mathrm{P}=0.045)$. Mean leves of fasting serum glucose

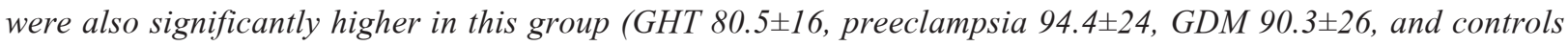
$78.6 \pm 10 \mathrm{mg} / \mathrm{dL} ; P=0.023)$. In the goups with complications mean levels of triglyceride were higher (GHT 267.7 \pm 61.5 ,

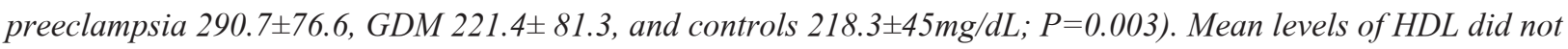
show any significant difference. The rate of the cases with metabolic syndrome according either to the criteria of WHO (GHT \%14.2, Preeclampsia \%45.2, GDM \%40, and controls \%2.5; p=0.001) or NCEP-ATPIII (GHT \%38, Preeclampsia \%45.4, GDM \%40, controls \%0; $p=0.001)$ was significantly higher in the groups of complications. Conclusions: We found that the criteria of metabolic syndrome and the rates of cases with MS were significantly higher in the groups of pregnancy complications compared with normal pregnancies. This finding indicates the relationship between both events. These cases have high risk for cardiovascular and metabolic diseases in later life.
\end{abstract}

Key words: gestational diabetes mellitus, insulin resistance, metabolic syndrome, obesity, preeclampsia

Journal of Turkish Society of Obstetrics and Gynecology, (J Turk Soc Obstet Gynecol), 2011; Vol: 8 Issue: 2 Pages: 100- 6

Address for Correspondence: Dr. Banu Dane. Emlak Bankası Konutları B1 Blok Daire 12 Fatih, İstanbul, Turkey Phone: +90 (212) 6217521

e-mail: Banudane@yahoo.com

Received: 12 July 2010, revised: 23 October 2010, accepted: 18 January 2011, online publication: 14 March 2011 


\section{ÖZET}

\section{GEBELIK KOMPLIKASYONLARI METABOLIK SENDROM KRITTERLERIYLE İLIŞKILIMIDİR?}

Amaç: Metabolik sendrom kriterlerine sahip olma açısından çeşitli gebelik komplikasyonları bulunan olgular ile normal gebelikler arasında fark olup olmadığını araştırmak amacıyla bu çalışma planland.

Gereç ve yöntemler: Çalışmaya kliniğimizde takip edilen 26. gebelik haftasının üzerinde 92 gebe dahil edildi. Kırk adet sağllkl gebeliği olan olgu ile gestasyonel hipertansiyon (21 olgu), gestasyonel diabetik (20 olgu) ve preeklamptik (11 olgu) olguların metabolik sendrom kriterlerine sahip olma oranları karşılaştırlld. Açlı serum total kolesterol, trigliserid, LDL ve HDL kolesterolü içeren açlık plasma lipid değerleri, açlık glukoz ve insülin değerleri tespit edildi. Insülin direnci için HOMA-IR kullanıldl.

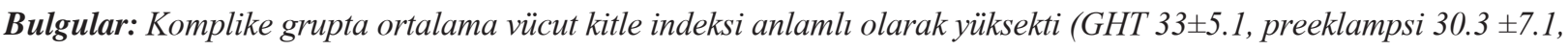
GDM 32.1 \pm 6.4 , kontrol grubunda $29.2 \pm 4.2 \mathrm{~kg} / \mathrm{m} 2 ; P: 0.045)$. Bu grupta ortalama açllk glikozu anlaml olarak yüksekti

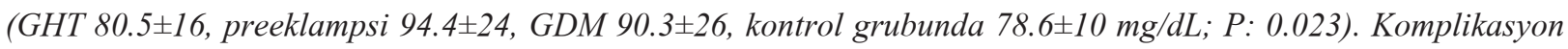

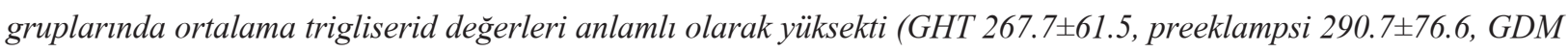
$221.4 \pm 81.3$, kontrol grubunda 218.3 $445 \mathrm{mg} / \mathrm{dL} ;$ P: 0.003). Ortalama HDL kolesterol değerleri gruplar arasinda anlaml fark göstermemekteydi. Metabolik sendrom tanısı alan olguların oranı hem WHO kriterlerine göre (GHT \%14.2, Preeklampsi \%45.2, GDM\%40, kontrol grubunda \%2.5; $p=0.001$ ) hem de NCEP-ATPIII kriterlerine göre (GHT\%38, Preeklampsi \%45.4, GDM\%40, kontrol grubunda \%0; p=0.001) komplikasyon grubunda anlaml olarak yüksek bulundu. Sonuç: Gebelik komplikasyonları bulunan grupta metabolik sendrom kriterlerinin ve MS tanısı koyulan olguların oranlarının normal gebelikler ile karşılaştırıldı̆̆ında daha fazla olduğunu tespit ettik. Bu bulgu her iki durumun arasındaki ilişkiyi göstermektedir. Bu olgular kardiyovasküler ve metabolik hastalıklar açısından ileriki hayatlarında da yüksek risk taşımaktadır.

Anahtar kelimeler: gestasyonel diabet, insülin direnci, metabolik sendrom, obezite, preeklampsi

Türk Jinekoloji ve Obstetrik Derneği Dergisi, (J Turk Soc Obstet Gynecol), 2011; Cilt: 8 Sayl: 2 Sayfa: 100- 6

\section{INTRODUCTION}

In 1998, World Health Organization put forward the term 'Metabolic syndrome' (MS), in order to identify the association of obesity, hypertension and dyslipidemia which are the disease and risk factors coexisting with Type 2 diabetes mellitus, known formerly as insulin resistance syndrome(1). Environmental factors such as adopting a sedentary lifestyle and changes in nutritional habits as well as some inherited characteristics play significant roles. Nowadays, it has been demonstrated that metabolic syndrome is an important risk factor in terms of cardiovascular and metabolic diseases $(2,3)$.

Partial insulin resistance, increased adiposity and hyperlipidemia occurring during pregnancy complicate the usage of MS classic diagnosis criteria. Even though the pregnancy progresses normally, it may be regarded as stress test in terms of carbohydrate, lipid and cardiovascular physiology(4). In the research of Bartha et al(5), MS frequency was determined in about one third of hypertension cases related to pregnancy and in about $10 \%$ of late-onset gestational diabetes cases. In the research done by Akinci et $\mathrm{al}^{(6)}$, it was stated that fasting glucose value $(>100 \mathrm{mg} / \mathrm{dL})$ during pregnancy can provide prediction in terms of metabolic syndrome that might develop after pregnancy. The fact that mild glucose intolerance that emerges in GDM and during pregnancy is associated with increase in metabolic syndrome possibility even in early postpartum period ( 3 months), gives rise to the thought that both situations may be the symptoms of latent metabolic syndrome ${ }^{(7)}$. Preeclamptic cases are at increased risk concerning metabolic syndrome and ischemic heart disease that may emerge later ${ }^{(8-12)}$. Metabolic syndrome diagnosis during pregnancy is significant in terms of determining the women at risk regarding onwards cardiovascular and metabolic changes.

The aim of this study is to research metabolic syndrome frequency in the cases of late-onset gestational diabetes and hypertension related to pregnancy and in normal pregnancies by using the definitions of World Health 
Organization (WHO) and National Cholesterol Education Program Adult Treatment Panel III (NCEPATP III).

\section{METHOD AND MATERIALS}

92 singleton pregnant women who attended to Haseki Training and Research Hospital, Obstetrics and Gynecology Clinic or Polyclinic between the dates August 2008-February 2009 were involved in this research. Cases were divided into four groups: 40 healthy pregnant women as the control group, 11 preeclamptic cases, 21 cases with pregnancy related hypertension, 20 cases with gestational diabetes mellitus.

Study was approved by the ethics committee of our hospital and verbal approval was taken from all the cases involved. The criteria used to determine the cases are presented below:

a. Control group: Pregnant women who are non diabetic, normotensive and whose maternal age is compatible with pregnancy week were determined. These cases maintained normotensive through pregnancy and postpartum period.

b. Hypertension group: Cases without hypertension before pregnancy and with a blood pressure of $\geq 140 / 90 \mathrm{mmHg}$ in two measurements done at minimum of 4 hours intervals after the 20 . week of pregnancy were selected. These cases were divided into two as gestational hypertension (hypertension related to pregnancy with non proteinuira) and preeclampsia (hypertension related to pregnancy with proteinuira).

Proteinuira: Appereance of $\geq 300 \mathrm{mg}$ proteinuira in $\geq 2+$ or $24 \mathrm{hr}$ in spot urine was regarded as proteinuric.

c. Diabetes group: The case was regarded as gestational diabetic if two or more values were high in 100 gr oral glucose tolerance test of the women who were healthy before pregnancy.

Limit values were accepted as (Fasting 95, 1.hr 180, 2.hr 155 and $3 . \mathrm{hr} 140 \mathrm{mg} / \mathrm{dL}$ ) in the oral glucose tolerance test. Cases that had the GDM diagnosis in the early pregnancy weeks ( $<14$ th week) weren't involved in the study because of the probability that they may have been diabetic before pregnancy.
For metabolic syndrome diagnosis during pregnancy, metabolic syndrome frequencies were calculated by using WHO and NCEP-ATP III definitions.

\section{A. Metabolic Syndrome Diagnosis Criteria of WHO During Pregnancy(5).}

- Insulin resistance (presence of one of the following):

- Type 2 DM, high fasting glucose $(\geq 105 \mathrm{mg} / \mathrm{dL})$, insulin resistance determined by any method,

- Presence of two or more of the following criteria

- Hypertension (>140/90 mg/dL) and/or antihypertensive usage

- Triglyceride $\geq 2$ SD for the pregnancy week

- HDL-Cholesterol $\leq 2 \mathrm{SD}$ for the pregnancy week

- Waste/hip ratio $>0,85$ and/or Body mass index $(\mathrm{BMI})>30 \mathrm{~kg} / \mathrm{m} 2$

\section{B. Metabolic Syndrome Diagnosis Criteria of NCEP-ATP III During Pregnancy(5).}

With the presence of 3 or more of the following criteria, MS diagnosis is set.

- Central obesity, waist circumference>2SD in the first half of pregnancy or BMI $>30$ $\mathrm{kg} / \mathrm{m} 2$

- Triglyceride $\geq 2$ SD for the pregnancy week

- HDL-Cholesterol $\leq 2 \mathrm{SD}$ for the pregnancy week

- Systolic Blood Pressure $\geq 130$ and/or Diastolic B. P. $\geq 85 \mathrm{mmHg}$

- Fasting Blood Pressure (FBP) $\geq 105 \mathrm{mg} / \mathrm{dL}$

Insulin Resistance: Fasting insulin was measured in Haseki Training and Research Hospital, Biochemistry Laboratory with a device called ARCHITECT 16200 by using ABOTT KITS and regarding 3-17 ulU/ml as the reference range. Insulin resistance was calculated by Homeostasis Model Assesment (HOMA) formula: Fasting Insulin x Fasting Glucose / 405. Cases which had a HOMA value of 2.5 or more or a fasting blood glucose value of $\geq 105 \mathrm{mg} / \mathrm{dl}$ were regarded as insulinresistant. All the cases with gestational diabetes were also regarded as insulin-resistant.

Body Mass Index: Heights and weights of the pregnant women enrolled were measured and their body mass 
indexes (BMI) were calculated with the formula [weight $(\mathrm{kg}) /$ height $(\mathrm{m}) 2]$. The cases that have a BMI $\geq 30$ $\mathrm{kg} / \mathrm{m} 2$ were regarded as obese.

Biochemistry Data: Total fasting plasma lipid values containing cholesterol, triglyceride, LDL and HDL cholesterol, fasting glucose and insulin values were determined by taking about $10 \mathrm{ml}$ blood on the day of inspection and the following day. Laboratory staff evaluating the blood biochemistry were blinded to the hypothesis of the study and status of the cases.

Hypertriglyceridemia: Because of the small number of cases, fasting plasma triglyceride value was regarded as high in the case that it is $\geq 281 \mathrm{mg} / \mathrm{dL}$ (mean+ISD).

HypoHDL: Because of the small number of cases, fasting plasma HDL value was regarded as low in the case that it is $\leq 42 \mathrm{mg} / \mathrm{dL}$ (mean+ISD).

In the adaptation of metabolic syndrome to pregnancy, following points were taken into consideration: 1) Insulin resistance diagnosis was set according to HOMA analysis and fasting blood glucose values. Besides, it was supposed that in all the gestational diabetes cases insulin resistance was present. 2) Because the waist circumference may increase in the second half of pregnancy due to different reasons (such as fetal macrosomia, polyhydramniosis), it wasn't regarded as an obesity criteria.

\section{Statistics}

Qualitative values were expressed as number of the cases and percentages. Ratios were compared via chisquare test. Quantitative values were expressed as mean \pm S.D. Differences between groups were evaluated via student ANOVA test (one-way analysis of variance). Calculations were done with Medcalc statistics program. It was regarded as significant when $\mathrm{P}$ value was $<0.05$.

\section{RESULTS}

Demographical results were presented in Table I and compared. No significant difference was determined between groups regarding mean maternal age, nulliparous ratio, mean gravidity and parity. Number of cases with at least one abortus or stillbirth anamnesis didn't show a significant difference either.

Distribution of risk factors among groups and significance level of the differences were compared and presented in Table II. Mean BMI values were significantly higher in hypertension and gestational diabetes groups. Triglyceride values were the highest in preeclampsia group and showed significant difference among groups. No significant difference was seen in terms of HDL cholesterol values. In the cases with complications, mean systolic and diastolic blood

Table I: Comparison of demographical results of the cases

\begin{tabular}{|c|c|c|c|c|c|}
\hline & $\begin{array}{l}\text { Gestational } \\
\text { Hypertension } \\
(\mathrm{n}=21)\end{array}$ & $\begin{array}{l}\text { Preeklampsia } \\
(n=11)\end{array}$ & $\begin{array}{l}\text { Gestational } \\
\text { Diabetes } \\
(\mathbf{n}=\mathbf{2 0})\end{array}$ & $\begin{array}{l}\text { Control } \\
(n=40)\end{array}$ & $P$ value \\
\hline Maternal age (year) & $29.4 \pm 5.3$ & $29.2 \pm 5.9$ & $32.7 \pm 1.6$ & $30.2 \pm 5.1$ & 0.178 \\
\hline Week of pregnancy & $35.2 \pm 2.6$ & $33.3 \pm 1.6$ & $32.4 \pm 3.8$ & $33.7 \pm 3.6$ & 0.06 \\
\hline Nulliparous N (\%) & $4(\% 19)$ & $5(\% 45)$ & $4(\% 20)$ & $14(\% 35)$ & 0.27 \\
\hline Gravidity & $3.6 \pm 1.9$ & $2.6 \pm 1.8$ & $3.3 \pm 1.6$ & $2.9 \pm 2.1$ & 0.5 \\
\hline Parity & $2 \pm 1.68$ & $1 \pm 1$ & $1.7 \pm 1.2$ & $1.5 \pm 1.8$ & 0.37 \\
\hline Abortus anamnesis N (\%) & $7(\% 33)$ & $3(\% 27)$ & $3(\% 15)$ & $8(\% 20)$ & 0.5 \\
\hline Stillbirth anamnesis N(\%) & $3(\% 14)$ & $0(\% 0)$ & $2(\% 10)$ & $0(\% 0)$ & 0.07 \\
\hline
\end{tabular}

Table II: Distribution of risk factors among the groups and significance level of differences.

\begin{tabular}{lllll}
\hline & $\begin{array}{l}\text { Gestational } \\
\text { Hypertension } \\
(\mathbf{n = 2 1 )}\end{array}$ & $\begin{array}{l}\text { Preeklampsia } \\
(\mathbf{n = 1 1})\end{array}$ & $\begin{array}{l}\text { Gestational } \\
\text { Diabetes } \\
(\mathbf{n = 2 0})\end{array}$ & $\begin{array}{l}\text { Control } \\
(\mathbf{n = 4 0})\end{array}$ \\
\hline BMI (kg/m2) & $33 \pm 5.1$ & $30.3 \pm 7.1$ & $32.1 \pm 6.4$ & $29.2 \pm 4.2$ \\
Fasting blood glucose (mg/dL) & $80.5 \pm 16$ & $94.4 \pm 24$ & $90.3 \pm 26$ & $78.6 \pm 10$ \\
Triglyceride(mg/dL) & $267.7 \pm 61.5$ & $290.7 \pm 76.6$ & $221.4 \pm 81.3$ & $218.3 \pm 62.7$ \\
HDL cholesterol (mg/dL) & $60.9 \pm 14.8$ & $59.1 \pm 16.5$ & $60.7 \pm 10.2$ & $56.2 \pm 13.9$ \\
Systolic blood pressure (mmHg) & $145.2 \pm 7.5$ & $163.6 \pm 28$ & $129.5 \pm 13$ & 0.045 \\
Diastolic blood pressure $(\mathrm{mmHg})$ & $96.6 \pm 7.9$ & $100 \pm 11.8$ & $76 \pm 16.9$ & 0.52 \\
\hline
\end{tabular}


pressure values were found significantly high.

Distribution of metabolic syndrome components among groups and their significance levels were given in Table III. While no difference was seen regarding obesity and hypo HDL ratios, insulin resistance, fasting hyperglycemia, hypertriglycemia and hypertension frequency were significantly high in the cases with complications. Hypertensive case frequency was significantly high as expected in gestational hypertension and preeclampsia groups.

Distribution of metabolic syndrome frequencies according to WHO and NCEP-ATP III criteria was presented in Table IV. It was supposed that insulin resistance is present in gestational diabetes cases. In the statistical evaluation it was determined that metabolic syndrome frequency is significantly high especially in preeclampsia and gestational diabetes cases.

\section{DISCUSSION}

Most of the risk factors that are involved in metabolic syndrome are regarded as risk factors also for development of preeclampsia. MS, at the same time, provides the relation between preeclampsia and cardiovascular diseases $(\mathrm{CVD})^{(13)}$. It is not understood whether preeclampsia creates a tendency towards future CVD in the cases with moderate MS or functions as a test that provides the cases with tendency towards MS and CVDs to emerge during pregnancy. Presence of metabolic syndrome criteria alone or in different combinations during pregnancy was researched and shown to be an independent risk factor especially regarding the development of serious $\operatorname{preeclampsia}^{(14)}$

In gestational diabetes cases, presence of metabolic syndrome criteria was stated by Szymanska et al(15). In this research, presence of significant high arterial blood pressure, triglycerides, insulin and increased insulin resistance in GDM group was shown. Negrato et al ${ }^{(16)}$, on the other hand, showed as a result of their study that MS frequency increases proportionally with deterioration of glucose tolerance. In this study MS frequency was shown as $0 \%, 20 \%, 23.5 \%$ and $36.4 \%$ in the cases of normoglycemia, mild hyperglycemia, GDM and open GDM respectively. In the consequence of the study it was suggested that even in the cases that are defined as OGTT normal according to today's criteria, increased blood glucose values can determine the pregnancies with metabolic derangement that may cause serious perinatal results.

In our research HOMA index was used to evaluate the relation between complicated pregnancies and insulin resistance. HOMA-IR > 2,5 was the insulin resistance indicator. In all the gestational diabetes group cases, insulin resistance was regarded as present. Significant difference among the group regarding insulin resistance presence was determined (GHT 14\%, Preeclampsia 36\%, GDM 100\%, control group 10\%, P < 0.0001). When groups with complicated pregnancies were compared to the control group in our research, fasting blood glucose levels were found significantly high in the treatment group (GHT $80.5 \pm 16 \mathrm{mg} / \mathrm{dL}$, Preeclampsia $94.4 \pm 24 \mathrm{mg} / \mathrm{dL}$, GDM $90.3 \pm 26 \mathrm{mg} / \mathrm{dL}$, control group $78.6 \pm 10 \mathrm{mg} / \mathrm{dL}$;

Table III: Distribution of metabolic syndrome components among the groups and their significance levels.

\begin{tabular}{|c|c|c|c|c|c|}
\hline & $\begin{array}{l}\text { Gestational } \\
\text { Hypertension } \\
(\mathbf{n}=\mathbf{2 1})\end{array}$ & $\begin{array}{l}\text { Preeklampsia } \\
(n=11)\end{array}$ & $\begin{array}{l}\text { Gestational } \\
\text { Diabetes } \\
(n=20)\end{array}$ & $\begin{array}{l}\text { Control } \\
(n=40)\end{array}$ & $P$ value \\
\hline Insulin resistance $\mathrm{N}(\%)$ & $3(\% 14)$ & $4(\% 36)$ & $20(\% 100)$ & $4(\% 10)$ & $<0.0001$ \\
\hline Fasting hyperglycemia $(\geq 105 \mathrm{mg} / \mathrm{dL}) \mathrm{N}(\%)$ & )$(\% 4.7)$ & $4(\% 36)$ & $4(\% 20)$ & $1(\% 2.5)$ & 0.005 \\
\hline Obesity (BMI $\geq 30 \mathrm{~kg} / \mathrm{m} 2) \mathrm{N}(\%)$ & $16(\% 76)$ & $5(\% 45)$ & $13(\% 65)$ & $17(\% 42)$ & 0.056 \\
\hline Hypertriglyceridemia ( $\geq 281 \mathrm{mg} / \mathrm{dL}) \mathrm{N}(\%)$ & $8(\% 38)$ & $5(\% 45)$ & $4(\% 20)$ & $5(\% 12.5)$ & 0.042 \\
\hline Hyро HDL $(\leq 42 \mathrm{mg} / \mathrm{dL})$ & $2(\% 9,5)$ & $2(\% 18)$ & $1(\% 5)$ & $4(\% 10)$ & 0.69 \\
\hline $\begin{array}{l}\text { Hypertension WHO criteria } \\
(\geq 140 / 90 \mathrm{mmHg})\end{array}$ & $21(\% 100)$ & $11(\% 100)$ & $8(\% 40)$ & $0(\% 0)$ & $<0.0001$ \\
\hline
\end{tabular}

Table IV: Distribution of metabolic syndrome frequencies among the groups and their significance levels according to WHO and NCEP-ATP III criteria.

\begin{tabular}{lllll}
\hline $\begin{array}{l}\text { Metabolic Syndrome } \\
\text { diagnosis areas }\end{array}$ & $\begin{array}{l}\text { Gestational } \\
\text { Hypertension } \\
(\mathbf{n = 2 1 )}\end{array}$ & $\begin{array}{l}\text { Preeklampsia } \\
(\mathbf{n = 1 1 )}\end{array}$ & $\begin{array}{l}\text { Gestational } \\
\text { Diabetes } \\
(\mathbf{n = 2 0})\end{array}$ & $\begin{array}{l}\text { Control } \\
(\mathbf{n}=\mathbf{4 0})\end{array}$ \\
\hline WHO, N(\%) & $3(\% 14.2)$ & $5(\% 45.4)$ & $8(\% 40)$ & $1(\% 2.5)$ \\
NCEP-ATP III, N(\%) & $8(\% 38)$ & $5(\% 45.4)$ & $8(\% 40)$ & 0.001 \\
\hline
\end{tabular}


$\mathrm{P}: 0.023)$. Besides, ratio of the groups with high blood glucose $(\geq 105 \mathrm{mg} / \mathrm{dL})$ was significantly high especially in gestational diabetes and preeclampsia groups (GHT 4.7\%, Preeclampsia 36\%, GDM 20\%, control group $2.5 \%, \mathrm{P}=0.005)$.

It is estimated that frequency of hyper-triglyceridemia, one of the main components of MS, will increase with the growing number of obese young people. Ray et $\mathrm{al}^{(17)}$ have stated in a meta-analysis involving 10 casecontrol and 3 prospective cohort studies that preeclampsia risk increases significantly in the presence of hypertriglyceridemia. In the study done by Szymanska et al ${ }^{(15)}$, it was stated that higher serum triglyceride concentrations are present in the cases with GDM than the ones without diabetes $(247,9 \%$ to $205 \% \mathrm{mg} ; \mathrm{p}<0,01)$. According to the study of Wiznitzer et $\mathrm{al}^{(18)}$ in which they evaluated the lipid profile of 9911 cases starting from pre-pregnancy till post pregnancy; when the cases with lower triglyceride levels according to the pregnancy week and the cases with higher triglyceride were compared, the risk of preeclampsia or gestational diabetes development had increased (7,2\% to $19,8 \%$ ), but low HDL levels couldn't be associated with poor prognosis.

In our study as well, it was seen that triglyceride values were significantly higher especially in preeclampsia group (GHT 267.7 $\pm 61.5 \mathrm{mg} / \mathrm{dL}$, Preeclampsia $290.7 \pm 76.7 \mathrm{mg} / \mathrm{dL}$, GDM $221.4 \pm 81.3 \mathrm{mg} / \mathrm{dL}$, control group $218.3 \pm 62.7 ; \mathrm{P}=0.003)$. No significant difference was monitored in terms of mean HDL cholesterol values. In addition, ratio of the cases with high triglyceride level was significantly high in complicated pregnancies (GHT 38\%, preeclampsia 45\%, GDM $20 \%$; in control group $12.5 \%$; $\mathrm{P}=0.042$ ). However, no significant difference was monitored regarding the ratio of the cases with hypo-HDL (GHT 9.5\%, preeclampsia $18 \%$, GDM 5\%, control group $10 \%$; $\mathrm{P}=0.69)$.

HAPO test group has stated that high BMI values in the last period are strongly related with pregnancy complications (especially with macrosomia and preeclampsia) independent from maternal glucose values ${ }^{(19)}$. In our research it was determined that mean BMI values were significantly higher in gestational hypertension and gestational diabetes groups (GHT33 \pm 5.1 , Preeclampsia 30.3 \pm 7.1 , GDM 32.1 \pm 6.4 , control group $29.2 \pm 4.2 ; \mathrm{P}=0.045)$. Even though ratio of obese cases (BMI $\geq 30 \mathrm{~kg} / \mathrm{m}^{2}$ ) among the groups was high in GHT group, no significant difference was monitored (GHT 76\%, Preeclampsia 45\%, GDM 65\%, control group $42 \%$; $\mathrm{P}=0.056$ ).

There are also some studies in literature that associate the components of metabolic syndrome with preeclampsia in combinations. In a previous study of ours, it was determined that the presence of MS components in combinations increase the risk of hypertension related to pregnancy ${ }^{(20)}$. Mazar et al(14), on the other hand, used a scoring system made up of BMI, chronic hypertension and diabetes presence factors in a study (259 preeclamptic cases and 397 control cases) and they found that in the presence of more than 1 (OR 1.91, $\mathrm{P}=0.002$ ) or 2 factors (OR 2.65, $\mathrm{P}=0.001)$ the risk of preeclampsia increases significantly. In another research done by Srinivas et al, metabolic syndrome presence (3/5 component) and metabolic score value (between $0-5$ ) between normal and preeclamptic groups were compared and it was determined that risk of preeclampsia risk increased in metabolic syndrome presence (2.71 (1.1-6.67), $\mathrm{p}=0.03)$. With each value added to metabolic score, the risk of preeclampsia increased at a ratio of 39\%(21). When ratios of the cases with MS diagnosis were evaluated in our research, statistically significant difference was present among the groups according to the criteria of both WHO (GHT 14.2\%, Preeclampsia $45.2 \%$, GDM 40\%, control group 2.5\%; $\mathrm{p}=0.001$ ) and NCEP-ATP III (GHT 38\%, Preeclampsia 45.4\%, GDM $40 \%$, control group $0 \% ; \mathrm{P}=0.001$ ). This is showing that the results of the research done according to both criteria are significant and even if the criteria are used according to a different classification, this doesn't change the obtained result.

Limited number of cases and using the method of casecontrol in our research are seen as limitedness of the study. It is evident that monitoring the cases with metabolic syndrome in prospective-cohort way and comparing the pregnancies that will occur with pregnant women who don't have metabolic syndrome will enhance our knowledge of this topic.

Classification and diagnosis criteria of metabolic syndrome and some main criteria of hypertension and preeclampsia related to gestational diabetes, one of the pregnancy complications, are common. It can be suggested that MS components have a role in hypertensive incidents that occur during pregnancy, insulin resistance and related complications. Cases with 
complications compose a candidate group for future metabolic syndrome so they should be followed in terms of cardiovascular diseases after the pregnancy too.

\section{REFERENCES}

1. Alberti KGMM, Zimmet PZ for the WHO Consultation Definition, diagnosis and classification of diabetes mellitus and its complications. Part I. Diagnosis and classification of diabetes mellitus. Provisional report of a WHO consultation. Diabet Med 1998; 15: 539- 53

2. Lakka HM, Laaksonen DE, Lakka TA, Niskanen LK, Kumpusalo E, Tuomilehto, et al. The metabolic syndrome and total and cardiovascular disease mortality in middle-aged men. JAMA 2002; 288: 2709- 16

3. Lorenzo C, Okoloise M, Williams K, Stern MP, Haffner SM The metabolic syndrome as predictor of type 2 diabetes. The San Antonio Heart Study. Diabetes Care 2003; 26: 3153- 9.

4. Sattar N, Greer IA. Pregnancy complications and maternal cardiovascular risk: opportunities for intervention and screening? BMJ 2002; 325: 157- 60.

5. Bartha JL, Bugatto FG, Macias RF, Gonzalez NLG, Delgado $\mathrm{RC}$, Vivancos BH. Metabolic syndrome in normal and complicated pregnancies. Eur J Obstet Gynecol Reprod Biol 2008; 137: 178- 84 .

6. Akıncı B, Çeltik A, Yener S, Yeşil S. Prediction of developing metabolic syndrome after gestational diabetes mellitus. Fertil Steril 2010; 93: 1248- 54

7. Retnakaran R, Qi Y, Connelly PW, Sermer M, Zinman B, Hanley AJ. Glucose intolerance in pregnancy and postpartum risk of metabolic syndrome in young women. J Clin Endocrinol Metab 2010; 95: 670- 7 .

8. Forest JC, Girouard J, Masse J, Moutquin JM, Kharfi A, Ness RB, et al. Early occurence of metabolic syndrome after hypertension in pregnancy. Obstet Gynecol 2005; 105: 1373-80.

9. Sattar N, Greer IA. Pregnancy complications and maternal cardiovascular risk: opportunities for intervention and screening? BMJ 2002; 325: 157- 60.

10. Laivuori H, Tikkanen MJ, Ylikorkala O. Hyperinsulinaemia 17 years after pre-eclamptic first pregnancy. J Clin Endocrinol
Metab 1996; 81: 2908- 11

11. Smith GCS, Pell JP, Walsh D. Pregnancy complications and maternal risk of ischaemic heart disease: a retrospective cohort study of 129290 births. Lancet 2001; 357: 2002- 6

12. Girouard J, Giguere Y, Moutquin JM, Forest JC. Previous hypertensive disease of pregnancy is associated with alterations of markers of insulin resistance. Hypertension 2007; 49: 105662.

13. Rodie VA, Freeman DJ, Sattar N, Greer IA. Preeclampsia and cardiovascular risk: metabolic syndrome of pregnancy? Atherosclerosis 2004; 175: 189- 202

14. Mazar RM, Srinivas SK, Sammel MD, Andrela CM, Elovitz MA. Metabolic score as a novel approach to assessing preeclampsia risk. Am J Obstet Gynecol 2007; 197: 411e1$411 \mathrm{e} 5$.

15. Szymanska M, Bomba Opon DA, Wielgos M. Blood Pressure and lipid changes in gestational diabetes mellitus. Neuro Endocrinol Lett 2008; 29: 328- 33.

16. Negrato CA, Jovanovic L, Tambascia MA, Calderon Ide M, Geloneze B, Dias A, et al. Mild gestational hyperglycaemia as a risk factor for metabolic syndrome in pregnancy and adverse perinatal outcomes. Diabetes Metab Res Rev 2008; 24: 324- 30.

17. Ray JG, Diamond P, Singh G, Bell CM. Brief overview of maternal triglycerides as a risk factor for preeclampsia. BJOG 2006; 113: 379- 86 .

18. Wiznitzer A, Mayer A, Novack V, Sheiner E, Gilutz H, Malhotra A, et al. Association of lipid levels during gestation with preeclampsia and gestational diabetes mellitus: a population-based study. Am J Obstet Gynecol 2009; 201: 482 e1-8.

19. HAPO Study Cooperative Research Group. Hyperglycaemia and Adverse Pregnancy Outcome (HAPO) Study: associations with maternal body mass index. BJOG 2010; 117: 575-84.

20. Dane B, Dane C, Kıray M, Koldaş M, Çetin A. A new metabolic scoring system for analyzing the risk of hypertensive disorders of pregnancy. Arch Gynecol Obstet 2009; 280: 9214.

21. Srinivas SK, Sammel MD, Bastek J, Ofori E, Andrela CM, Wolfe ML, et al. Evaluating the association between all components of the metabolic syndrome and pre-eclampsia. J Matern Fetal Neonatal Med 2009; 22: 501- 9. 